\title{
Papers
}

\section{Systematic review of prevalence of aspirin induced asthma and its implications for clinical practice}

Christine Jenkins, John Costello, Linda Hodge

\begin{abstract}
Objective To reassess the prevalence of aspirin induced asthma and other issues related to the syndrome.

Data sources Biosis, SciSearch (1990 to March 2002), Embase (1974 to March 2002), Medline (1966 to March 2002), Toxline, Derwent Drug File (1964 to March 2002), Conference Papers Index and Inside Conferences, Int'l Pharmaceutical Abstracts, Pharma-Online (1978 to March 2002).

Selection criteria Study type, patient population, and outcome measures. Review was restricted to respiratory responses to analgesics available without prescription.

Results The prevalence of aspirin induced asthma was highest when determined by oral provocation testing (adults 21\%, 95\% confidence interval $14 \%$ to $29 \%$; children $5 \%, 0 \%$ to $14 \%$ ) than by verbal history (adults $3 \%, 2 \%$ to $4 \%$; children $2 \%, 1 \%$ to $3 \%$ ). Cross sensitivity to doses of over the counter non-steroidal anti-inflammatory drugs was present in most patients with aspirin induced asthma: ibuprofen, 98\%; naproxen, 100\%; and diclofenac, $93 \%$. The incidence of cross sensitivity to paracetamol among such patients was only $7 \%$.

Conclusions Aspirin induced asthma in adults is more prevalent than previously suggested. When there is a clinical necessity to use aspirin or a non-steroidal anti-inflammatory drug and there is uncertainty about safety, oral provocation testing should be performed.
\end{abstract}

\section{Introduction}

Aspirin induced asthma is a distinct clinical syndrome affecting some asthmatic patients. It is characterised by the onset of asthma 30 minutes to three hours after the ingestion of aspirin. Although the name of the condition relates to aspirin, it is well established that affected patients are cross sensitive to all non-steroidal anti-inflammatory drugs (NSAIDs) that inhibit cyclo-oxygenase (COX) enzymes. ${ }^{12}$ Paracetamol (acetaminophen), however, is seldom associated with cross sensitivity in patients with aspirin induced asthma. Emerging evidence shows that paracetamol may exert at least part of its analgesic effect through a newly identified COX-3 isoenzyme, whereas aspirin induced asthma is believed to involve inhibition of COX-1..$^{3-5}$

Despite a wealth of literature on aspirin induced asthma, controversy remains as to its prevalence, with published data ranging from $4 \%$ to $44 \%$. Differences in populations studied, methods used, definitions of outcomes, and criteria for defining sensitivity reactions may all be responsible for the variations in reported rates. ${ }^{6-8}$ A greater understanding of aspirin induced asthma is desirable, particularly given the increasing trend for consumers to treat themselves for minor painful conditions and the lack of association by many consumers between asthma and some analgesics. We performed a systematic review to reassess the prevalence of aspirin induced asthma in the general asthma population and to understand better the cross sensitivity of these individuals to commonly used non-prescription analgesics.

\section{Methods}

On 3 March 2002 we identified articles, in any language, with data on aspirin sensitivity among asthmatic patients and the use of paracetamol or NSAIDs. Additional articles were found through archives and the reference lists of identified articles. We excluded from the main analysis studies reporting nonrespiratory responses to analgesics, such as urticaria.

\section{Analysis of prevalence}

Most of the studies recruited from asthma clinics or hospitals where patients had presented with acute exacerbations. To account for preselection bias, we subdivided the participants into three groups: group 1, all patients with asthma-with or without

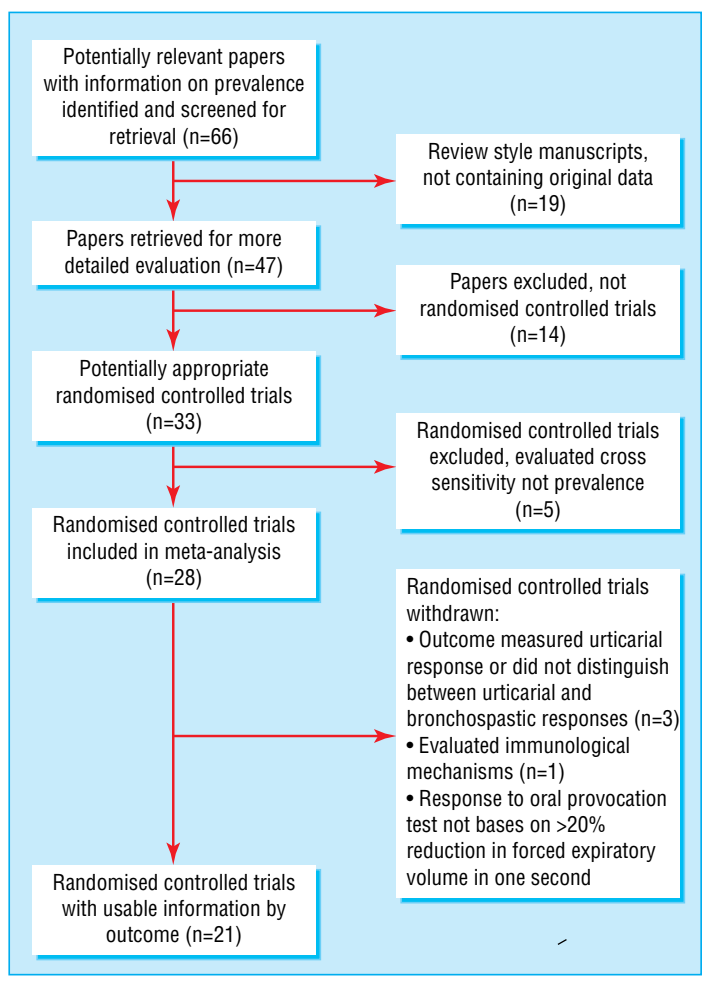

Fig 1 Inclusion of studies 
Table 1 Prevalence of aspirin induced asthma in adults, analysed by population and test method. Values are numbers (percentages) unless stated otherwise

\begin{tabular}{|c|c|c|c|c|c|c|}
\hline Trial & Study design & Study population & $\begin{array}{l}\text { Authors' definition of } \\
\text { positive response }\end{array}$ & $\begin{array}{l}\text { Oral provocation } \\
\text { testing }\end{array}$ & $\begin{array}{l}\text { Oral provocation } \\
\text { testing and verbal } \\
\text { history of aspirin } \\
\text { induced asthma }\end{array}$ & Verbal history alone \\
\hline \multicolumn{7}{|c|}{ Group 1: unselected asthma population* } \\
\hline Delaney $1976^{12}$ & $\begin{array}{l}\text { Double blind, placebo } \\
\text { controlled }\end{array}$ & $\begin{array}{l}\text { Outpatients: bronchodilators and } \\
\text { antihistamines withheld } 6-12 \text { hours } \\
\text { before testing, corticosteroids } \\
\text { allowed }\end{array}$ & $\begin{array}{l}\text { Reduction in } \mathrm{FEV}_{1} \geq 20 \% \\
\text { from baseline for up to } \\
\text { four hours }\end{array}$ & $44 / 230(19.1)$ & $118 / 304$ (38.7) & - \\
\hline Weber et al $1979^{15}$ & $\begin{array}{l}\text { Randomised, single } \\
\text { blind, placebo } \\
\text { controlled } \\
\end{array}$ & $\begin{array}{l}\text { Allergy and asthma clinic: no asthma } \\
\text { drugs taken } 12 \text { hours before testing }\end{array}$ & $\begin{array}{l}\text { Abnormal pulmonary function } \\
\text { test results, including } \\
\text { reduction in } \mathrm{FEV}_{1}>25 \%\end{array}$ & $15 / 30(50)$ & - & - \\
\hline $\begin{array}{l}\text { Stevenson et al } \\
1975^{11}\end{array}$ & $\begin{array}{l}\text { Single blind, placebo } \\
\text { controlled }\end{array}$ & $\begin{array}{l}\text { Female hospital patients with clinically } \\
\text { obvious asthma: put on restricted } \\
\text { diet, antihistamines omitted } 48 \text { hours } \\
\text { before testing, bronchodilator } \\
\text { treatment omitted six hours before } \\
\text { testing }\end{array}$ & $\begin{array}{l}\text { Reduction in peak expiratory } \\
\text { flow }>20 \%\end{array}$ & $31 / 122(24.6)$ & - & - \\
\hline Spector et al $1979^{14}$ & $\begin{array}{l}\text { Open challenge, patient } \\
\text { reporting }\end{array}$ & Hospital $(n=20)$, outpatient $(n=35)$ & Reduction in $\mathrm{FEV}_{1}>30 \%$ & $\begin{array}{c}9 / 55(16) \text {; incidence } \\
\text { was higher in hospital } \\
\text { patients than outpatients } \\
(35 \% \vee 6 \%)\end{array}$ & - & $8 / 55(15)$ \\
\hline Picardo et a $1^{16}$ & $\begin{array}{l}\text { Open challenge, patient } \\
\text { reporting }\end{array}$ & $\begin{array}{l}\text { Consecutive sample: hospital }(n=39) \text {, } \\
\text { outpatient }(n=35)\end{array}$ & Reduction in $\mathrm{FEV}_{1}>30 \%$ & $14 / 74(19)$ & - & $12 / 74(16)$ \\
\hline $\begin{array}{l}\text { Walton and Randle } \\
1957^{26}\end{array}$ & $\begin{array}{l}\text { Retrospective, medical } \\
\text { records }\end{array}$ & Private patients visiting allergist & Bronchospasm & - & - & $55 / 1775(3.1)$ \\
\hline $\begin{array}{l}\text { Castillo and Picado } \\
1986^{18}\end{array}$ & $\begin{array}{l}\text { Retrospective, } \\
\text { multicentre cohort with } \\
\text { questionnaire follow up }\end{array}$ & Intensive care unit & Not available & - & - & $\begin{array}{c}36 / 147 \text { (24.3); } \\
40 \% \text { in steroid } \\
\text { dependent } v 19 \% \text { in } \\
\text { non-steroid dependent } \\
\text { asthmatic patients }\end{array}$ \\
\hline $\begin{array}{l}\text { Towns and Mellis } \\
1984^{25}\end{array}$ & $\begin{array}{l}\text { Retrospective, medical } \\
\text { records }\end{array}$ & Asthma clinic & Not available & - & - & $24 / 1205(2.0)$ \\
\hline Fischer et al $1983^{24}$ & $\begin{array}{l}\text { Retrospective, medical } \\
\text { records }\end{array}$ & Asthma clinic & Not available & - & - & $69 / 2580(2.7)$ \\
\hline Total \% $(95 \% \mathrm{Cl}) \dagger$ & & & & $21.1(13.6,28.6)$ & $38.7(33.2,44.2)$ & $2.7(1.6,3.8)$ \\
\hline \multicolumn{7}{|c|}{ Group 2: preselected population with history of aspirin induced asthma $\ddagger$} \\
\hline Delaney $1976^{12}$ & $\begin{array}{l}\text { Double blind, placebo } \\
\text { controlled }\end{array}$ & $\begin{array}{l}\text { Outpatients: bronchodilators and } \\
\text { antihistamines withheld } 6-12 \text { hours } \\
\text { before testing; corticosteroids } \\
\text { allowed }\end{array}$ & $\begin{array}{l}\text { Reduction in } \mathrm{FEV}_{1} \geq 20 \% \\
\text { from baseline for up to four } \\
\text { hours }\end{array}$ & $29 / 59(49)$ & - & - \\
\hline Webber et al $1979^{15}$ & $\begin{array}{l}\text { Randomised, single } \\
\text { blind, placebo } \\
\text { controlled }\end{array}$ & $\begin{array}{l}\text { Allergy and asthma clinic: no asthma } \\
\text { drugs taken } 12 \text { hours before testing }\end{array}$ & $\begin{array}{l}\text { Abnormal pulmonary function } \\
\text { test results, including } \\
\text { reduction in } \mathrm{FEV}_{1}>25 \%\end{array}$ & 13/15 (87) & - & - \\
\hline $\begin{array}{l}\text { McDonald et al } \\
1972^{10}\end{array}$ & Single blind, controlled & Allergy clinic & $\begin{array}{l}\text { Rapid reduction in } \mathrm{FEV}_{1} \\
\geq 20 \%\end{array}$ & $41 / 87(47)$ & - & - \\
\hline Vally et al $2002^{8}$ & Single blind, controlled & $\begin{array}{l}\text { Allergy and asthma clinic: stable } \\
\text { asthma, usual maintenance drug } \\
\text { allowed }\end{array}$ & $\begin{array}{l}\text { Rapid reduction in } \mathrm{FEV}_{1} \\
>50 \%\end{array}$ & $8 / 42(19)$ & $22 / 282(8)^{\#}$ & \\
\hline $\begin{array}{l}\text { Stenius and Lemola } \\
1976^{13}\end{array}$ & Single blind, controlled & $\begin{array}{c}\text { Allergy and asthma clinic: first } \\
12 \text { patients had asthma drugs } \\
\text { withdrawn, remainder took usual } \\
\text { drugs } 1-2 \text { hours before attending } \\
\text { clinic }\end{array}$ & $\begin{array}{l}\text { Reduction in } \mathrm{FEV}_{1} \geq 25 \% \\
\text { from baseline }\end{array}$ & $13 / 39(34)$ & $20 / 45(44)$ & \\
\hline $\begin{array}{l}\text { Nizankowska et al } \\
2000^{9}\end{array}$ & $\begin{array}{l}\text { Single blind, controlled } \\
\text { retrospective analysis }\end{array}$ & Allergy and asthma clinic patients & $\begin{array}{l}\text { Rapid reduction in } \mathrm{FEV}_{1} \\
>50 \%\end{array}$ & $7 / 79(9)$ & - & - \\
\hline Falliers $1983^{17}$ & Open challenge & Outpatients & $\mathrm{FEV}_{1}>35 \%$ & 9/11 (82) & - & - \\
\hline $\begin{array}{l}\text { Kwoh and Feinstein } \\
1986^{6}\end{array}$ & $\begin{array}{l}\text { Three population } \\
\text { surveys }\end{array}$ & $\begin{array}{l}\text { Survey 1: metropolitan community, } \\
\text { hospital cohort }(n=150) \text {; survey } 2 \text { : } \\
\text { metropolitan community, members of } \\
\text { asthma foundation of Western } \\
\text { Australia ( } n=366) \text {; survey } 3 \text { : rural } \\
\text { community of Western Australia } \\
\text { ( } n=1298 \text {; asthmatic patients } n=128 \text { ) }\end{array}$ & Not available & - & - & $\begin{array}{l}17 / 150(11.3) \\
48 / 366(13.1) \\
14 / 128(10.9)\end{array}$ \\
\hline
\end{tabular}

\begin{tabular}{|c|c|c|c|c|c|c|}
\hline \multirow{2}{*}{\multicolumn{7}{|c|}{$\begin{array}{l}\text { Total }(95 \% \mathrm{Cl}) \dagger \\
\text { Group 3: pre-selected population with no history of sensitivity } \ddagger \\
\end{array}$}} \\
\hline & & & & & & \\
\hline Delaney $1976^{12}$ & $\begin{array}{l}\text { Double blind, placebo } \\
\text { controlled }\end{array}$ & $\begin{array}{l}\text { Outpatients: bronchodilators and } \\
\text { antihistamines withheld } 6-12 \text { hours } \\
\text { before testing; corticosteroids } \\
\text { allowed }\end{array}$ & $\begin{array}{l}\text { Reduction in } \mathrm{FEV}_{1} \geq 20 \% \\
\text { from baseline for up to } \\
4 \text { hours }\end{array}$ & 15/171 (8.7) & - & - \\
\hline Weber et al ${ }^{15}$ & $\begin{array}{l}\text { Randomised, single } \\
\text { blind, placebo } \\
\text { controlled }\end{array}$ & $\begin{array}{l}\text { Allergy and asthma clinic: no asthma } \\
\text { drugs taken } 12 \text { hours before testing. }\end{array}$ & $\begin{array}{l}\text { Abnormal pulmonary function } \\
\text { test results, including } \\
\text { reduction in } \mathrm{FEV}_{1}>25 \%\end{array}$ & $2 / 15(13)$ & - & - \\
\hline Total $(95 \% \mathrm{Cl})$ ) & & & & 9.0 (3.7 to 14.3) & - & - \\
\hline
\end{tabular}

$\mathrm{FEV}_{1}=$ forced expiratory volume in one second.

*Includes patients with and without a history of aspirin induced asthma and with and without markers of increased risk or likelihood of aspirin induced asthma. †Included patients with history of aspirin induced asthma or with markers of increased risk or likelihood of aspirin induced asthma. łlncluded patients without a history of aspirin induced asthma or without markers of increased risk or likelihood of aspirin induced asthma. §Authors noted this to be underestimation and said real prevalence in population to would be 10-16\%. ICalculated from pooling incidence rates in individual studies. 
a history of aspirin induced asthma and with or without markers of an increased risk or likelihood of the syndrome; group 2, patients preselected on the basis that they had either a reliable history of aspirin induced asthma or markers of an increased risk or likelihood of the syndrome; and group 3, patients with no markers of an increased risk or likelihood of aspirin induced asthma.

The primary outcome was to determine whether the ingestion of aspirin triggered an asthmatic response. For this reason we included in the main analysis only studies in which patients underwent provocation challenges. Our analysis defined a positive aspirin induced asthma response as a $20 \%$ or more reduction in forced expiratory volume in one second within three or four hours of the challenge, as recently described. ${ }^{9}$

Owing to the potential for severe reactions in patients with aspirin induced asthma, provocation challenges in patients with an unequivocal history of aspirin sensitivity is deemed unethical. In view of this, many authors had combined the results from such patients with the number of patients showing a positive reaction to provocation challenge; we included such studies in a subanalysis.

The use of history alone for determining aspirin sensitivity among asthmatic patients has underestimated and overestimated prevalence. Therefore we also conducted a subanalysis of papers in which history was the only means of determining aspirin sensitivity.

\section{Analysis of incidence of cross sensitivity to NSAIDs or paracetamol}

In the analysis of cross sensitivity we included only level 1 studies representing properly controlled, randomised, and single blinded or double blinded clinical trials. The primary outcome was to determine whether the ingestion of NSAIDs (specifically ibuprofen, naproxen, and diclofenac) or paracetamol triggered an asthmatic response in patients who had been positively iden- tified as having aspirin induced asthma by oral provocation testing, history, or both. Studies were only included for analysis if cross sensitivity to NSAIDs or paracetamol was determined by provocation challenge.

\section{Statistical analysis}

Using a weighted average of the incidence rates from individual studies, we calculated pooled incidence rates and $95 \%$ confidence intervals. The reciprocal of the variance in each study was calculated for weighting.

\section{Results}

\section{Prevalence in adults}

A total of 66 papers were identified that gave the prevalence for aspirin induced asthma. Only 21 (15 in adults and six in children) were eligible for inclusion in our analysis (fig 1). ${ }^{8}$ 10-29 Although a double blind trial would produce more robust data, this is not the usual method employed for studies of aspirin induced asthma owing to the high risk of life threatening reactions. Only four of the trials were double blind.

The pooled incidence of aspirin induced asthma was 21\% ( $95 \%$ confidence interval $14 \%$ to $29 \%$ ), regardless of whether the patients had a history of aspirin induced asthma or markers for an increased risk of the syndrome (table 1). Prevalence of aspirin induced asthma also seemed to depend on the method used to determine it, with history alone resulting in a much lower prevalence $(2.7 \%)$. Four of the studies in adults gave data on the number of patients reacting to different doses of aspirin. ${ }^{12} 141517$ Around half $(57 / 113)$ of those who had positive reactions, did so at low doses of aspirin $(\geq 80 \mathrm{mg})$, indicating that they were highly sensitive.

\section{Prevalence in children}

Aspirin induced asthma has been considered rare in children, yet we found that although it is less common in children than in

Table 2 Prevalence of aspirin induced asthma in children, analysed by population and test method. Values are numbers (percentages) unless stated otherwise

\begin{tabular}{|c|c|c|c|c|c|c|c|}
\hline Trial & Study design & $\begin{array}{l}\text { Mean age } \\
\text { (years) }\end{array}$ & Study population & $\begin{array}{l}\text { Authors' definition of } \\
\text { positive response }\end{array}$ & $\begin{array}{l}\text { Oral provocation } \\
\text { testing }\end{array}$ & $\begin{array}{c}\text { Oral provocation } \\
\text { testing and verbal } \\
\text { history of aspirin } \\
\text { induced asthma }\end{array}$ & $\begin{array}{l}\text { Verbal history } \\
\quad \text { alone }\end{array}$ \\
\hline \multicolumn{8}{|c|}{ Group 1: Unselected asthma population*: } \\
\hline $\begin{array}{l}\text { Marquett et al } \\
1992^{20}\end{array}$ & $\begin{array}{l}\text { Randomised, double } \\
\text { blind, placebo controlled }\end{array}$ & 13.5 & $\begin{array}{l}\text { Asthma clinic: } \\
\text { moderately severe } \\
\text { asthma }\end{array}$ & $\begin{array}{l}\text { Reduction in } \mathrm{FEV}_{1}>2 \mathrm{SD} \\
\text { from mean placebo response } \\
\text { (all positives were }>20 \% \\
\text { reduction in } \mathrm{FEV}_{1} \text { ) }\end{array}$ & $5 / 54(9)$ & $7 / 56(13)$ & - \\
\hline $\begin{array}{l}\text { Rachelefsky et } \\
\text { al } 1975^{21}\end{array}$ & Open challenge & 9.6 & Outpatients & $\begin{array}{l}\text { Reduction in peak expiratory } \\
\text { flow rate } \geq 20 \%\end{array}$ & $0 / 32(0)$ & - & - \\
\hline $\begin{array}{l}\text { Schuhl and } \\
\text { Pereyra } 1979^{23}\end{array}$ & Single blind & 9.0 & $\begin{array}{c}\text { Asthma clinic: chronic } \\
\text { asthma }\end{array}$ & $\begin{array}{l}\text { Reduction in peak expiratory } \\
\text { flow rate and } \mathrm{FEV}_{1} \geq 20 \%\end{array}$ & $6 / 29(20.7)$ & - & - \\
\hline Pearson $1963^{27}$ & Medical records & Range 6-16 & Allergy and asthma clinic & Not available & - & - & 25/1298 (1.9) \\
\hline Total $(95 \% \mathrm{Cl}) \dagger$ & - & - & - & - & $5.0(0$ to 14.0$) \ddagger$ & 12.5 (3.8 to 21.2$)$ & $1.9(1.2$ to 2.6$)$ \\
\hline \multicolumn{8}{|c|}{ Group 3: Preselected population with no history of sensitivity§: } \\
\hline $\begin{array}{l}\text { Vedanthan et al } \\
1997^{22}\end{array}$ & $\begin{array}{l}\text { Double blind, placebo } \\
\text { controlled }\end{array}$ & 12.5 & $\begin{array}{c}\text { Outpatients, chronic } \\
\text { asthma (severity varied). } \\
\text { All drugs discontinued } \\
12 \text { hours before testing }\end{array}$ & Reduction in $\mathrm{FEV}_{1}>20 \%$ & $3 / 25(12)$ & - & - \\
\hline $\begin{array}{l}\text { Milosevic } \\
1990^{19}\end{array}$ & $\begin{array}{l}\text { Double blind, placebo } \\
\text { controlled }\end{array}$ & 13.6 & Allergy clinic & $\begin{array}{l}\text { Reduction in } \mathrm{FEV}_{1} \geq 30 \% \\
\text { from baseline for up to four } \\
\text { hours }\end{array}$ & $9 / 50(18)$ & - & - \\
\hline Total $(95 \% \mathrm{Cl}) \dagger$ & - & - & - & - & 15.5 (4.2 to 26.8 ) & - & - \\
\hline
\end{tabular}

$\mathrm{FEV}_{1}=$ forced expiratory volume in one second.

No studies found for preselected population with a history of aspirin induced asthma or with markers of increased risk or likelihood of aspirin induced asthma (group 2).

*Includes patients with and without history of aspirin induced asthma and with and without markers of increased risk or likelihood of aspirin induced asthma.

tCalculated from pooling incidence rate in individual studies.

łLower bound truncated at 0 .

§Includes patients without history of aspirin induced asthma or without markers of increased risk or likelihood of aspirin induced asthma. 
Table 3 Incidence of cross sensitivity to NSAIDs among patients with aspirin induced asthma

\begin{tabular}{|c|c|c|c|c|c|c|c|c|c|}
\hline Trial & Study design & Age (years) & Study population & $\begin{array}{l}\text { Authors' definition of } \\
\text { positive response }\end{array}$ & $\begin{array}{l}\text { Maximum } \\
\text { challenge } \\
\text { dose }(\mathrm{mg})\end{array}$ & $\begin{array}{l}\text { Subjects } \\
\text { tested }\end{array}$ & $\begin{array}{l}\text { Positive } \\
\text { outcome }\end{array}$ & Incidence (\%) & $\begin{array}{l}\text { Sensitivity } \\
\text { previously } \\
\text { proved by } \\
\text { challenge }\end{array}$ \\
\hline \multicolumn{10}{|l|}{ Ibuprofen: } \\
\hline $\begin{array}{l}\text { Chafee and } \\
\text { Settipane } \\
1974^{28}\end{array}$ & $\begin{array}{l}\text { Double blind, } \\
\text { placebo controlled }\end{array}$ & $16-60$ & $\begin{array}{l}\text { Allergy and clinical } \\
\text { immunology } \\
\text { department }\end{array}$ & $\begin{array}{l}\text { Reduction in peak } \\
\text { expiratory flow }>15 \% \\
\text { (positive reactions } \\
\text { ranged from 19-68\%) }\end{array}$ & 300 & 18 & 18 & 100 & Yes \\
\hline $\begin{array}{l}\text { Szczeklik et al } \\
1977^{1}\end{array}$ & $\begin{array}{l}\text { Double blind, } \\
\text { placebo controlled }\end{array}$ & $16-68$ & $\begin{array}{l}\text { Allergy and clinical } \\
\text { immunology } \\
\text { department }\end{array}$ & $\begin{array}{l}\text { Reduction in peak } \\
\text { expiratory flow } \\
16-25 \% \text { and clinical } \\
\text { symptoms of } \\
\text { bronchial obstruction } \\
\text { or reduction in in } \\
\text { peak expiratory flow } \\
>25 \% \text { with no } \\
\text { symptoms }\end{array}$ & 400 & 31 & 30 & 97 & Yes \\
\hline Total $(95 \% \mathrm{Cl})^{*}$ & - & Not available & - & - & Not available & - & - & 98 (90 to 100$) \dagger$ & - \\
\hline \multicolumn{10}{|l|}{ Naproxen: } \\
\hline $\begin{array}{l}\text { Szczeklik et al } \\
1077^{1}\end{array}$ & $\begin{array}{l}\text { Double blind, } \\
\text { placebo } \\
\text { controlled }\end{array}$ & $16-68$ & $\begin{array}{l}\text { Allergy and clinical } \\
\text { immunology } \\
\text { department }\end{array}$ & $\begin{array}{l}\text { Reduction in peak } \\
\text { expiratory flow } \\
16-25 \% \text { and clinical } \\
\text { symptoms of } \\
\text { bronchial obstruction } \\
\text { or reduction in peak } \\
\text { expiratory flow }>25 \% \\
\text { with no symptoms }\end{array}$ & 100 & 11 & 11 & 100 & Yes \\
\hline Falliers $1973^{29}$ & $\begin{array}{l}\text { Double blind, } \\
\text { placebo } \\
\text { controlled }\end{array}$ & Mean 39 & $\begin{array}{l}\text { Allergy and clinical } \\
\text { immunology } \\
\text { department }\end{array}$ & $\begin{array}{c}\text { Reduction in peak } \\
\text { expiratory flow }>20 \% \\
\text { up to four hours after } \\
\text { dose }\end{array}$ & 80 & 11 & 11 & 100 & Yes \\
\hline Total $(95 \% \mathrm{Cl})^{*}$ & - & - & - & - & Not available & - & - & $100(83$ to 100$) \dagger$ & - \\
\hline \multicolumn{10}{|l|}{ Diclofenac: } \\
\hline $\begin{array}{l}\text { Szczeklik et al } \\
1977^{1}\end{array}$ & $\begin{array}{l}\text { Double blind, } \\
\text { placebo } \\
\text { controlled }\end{array}$ & $16-68$ & $\begin{array}{l}\text { Allergy and clinical } \\
\text { immunology department }\end{array}$ & $\begin{array}{l}\text { Reduction in peak } \\
\text { expiratory flow } \\
16-25 \% \text { and clinical } \\
\text { symptoms of } \\
\text { bronchial obstruction } \\
\text { or reduction in peak } \\
\text { expiratory flow }>25 \% \\
\text { with no symptoms }\end{array}$ & 40 & 14 & 12 & 86 & Yes \\
\hline Falliers $1973^{29}$ & $\begin{array}{l}\text { Double blind, } \\
\text { placebo } \\
\text { controlled }\end{array}$ & Mean 39 & $\begin{array}{l}\text { Allergy and clinical } \\
\text { immunology department }\end{array}$ & $\begin{array}{c}\text { Reduction in peak } \\
\text { expiratory flow }>20 \% \\
\text { up to four hours after } \\
\text { dose }\end{array}$ & 25 & 11 & 11 & 100 & Yes \\
\hline Total $(95 \% \mathrm{CI})^{*}$ & - & Not available & - & - & Not available & - & - & 93 (76 to 100)† & - \\
\hline
\end{tabular}

${ }^{*}$ Calculated from pooling incidence rate in individual studies.

tUpper bound truncated at 100

adults, prevalence is still around 5\% (0\% to 14\%) when children are subject to oral provocation testing (table 2). ${ }^{21}{ }^{23}{ }^{25}$ Although only one of the studies was a double blind, randomised controlled trial, it accounted for almost half of the patients in our analysis. ${ }^{21}$ As with adults, the use of history alone gave a lower estimate of prevalence $(2 \%, 1 \%$ to $3 \%)$ than determined by oral provocation testing.

\section{Incidence of cross sensitivity}

Over the counter NSAIDs

Ten studies reported the incidence of cross sensitivity to three commonly used NSAIDs (ibuprofen, naproxen, diclofenac). Only three of these were level 1 studies eligible for inclusion. ${ }^{130} 31$ Based on these, the incidence of cross sensitivity was: $\leq 400 \mathrm{mg}$ ibuprofen, $98 \%$ (95\% CI $90 \%$ to $100 \%$ ); $\leq 100 \mathrm{mg}$ naproxen, $100 \%(83 \%$ to 100$)$; and $\leq 40 \mathrm{mg}$ diclofenac, $93 \%(76 \%$ to $100 \%$; table 3$).^{130}{ }^{31}$

Cross sensitivity to paracetamol

Each article on cross sensitivity to paracetamol was classified according to its methods. Ten of 52 identified papers were of level 1 studies. ${ }^{1}{ }^{12} 14172432-36$ Table 4 summarises the data for these studies, except for one in which the authors report the number of oral provocation tests and reactions but not the number of patients with a positive reaction. ${ }^{36}$ Of 268 adults and children with aspirin induced asthma who underwent oral challenge, only 32 had a positive respiratory reaction to paracetamol (pooled incidence $7 \%, 0 \%$ to $16 \%$ ).

\section{Discussion}

The prevalence of aspirin induced asthma is $21 \%$ for adults and $5 \%$ for children according to our systematic review. Our review is, however, limited by the retrospective nature of the analysis and the heterogeneity of the patient population. We were unable to attain the clinical status of all the patients, there was a lack of uniformity with the challenge tests, and some studies included only a small number of patients. Clinical heterogeneity was overcome by analysing different patient populations separately, and the findings are strengthened by the distinction between adults and children and the types of testing involved (oral provocation testing, patient history, questionnaire). Prospective studies in the general asthma population-correlating questionnaire responses 
Table 4 Incidence of cross sensitivity to paracetamol among patients with aspirin induced asthma

\begin{tabular}{|c|c|c|c|c|c|c|c|c|c|}
\hline Trial & Study design & Age (years) & Study population & $\begin{array}{l}\text { Authors' definition of } \\
\text { positive response }\end{array}$ & $\begin{array}{l}\text { Maximum } \\
\text { challenge dose } \\
(\mathrm{mg})\end{array}$ & $\begin{array}{l}\text { No of } \\
\text { participants } \\
\text { tested }\end{array}$ & $\begin{array}{l}\text { Positive } \\
\text { outcome }\end{array}$ & Incidence (\%) & $\begin{array}{l}\text { Sensitivity } \\
\text { previously } \\
\text { proved by } \\
\text { challenge }\end{array}$ \\
\hline $\begin{array}{l}\text { Settipane et } \\
\text { al } 1995^{33}\end{array}$ & $\begin{array}{l}\text { Single blind, } \\
\text { controlled }\end{array}$ & Mean 48.3 & Allergy office & Reduction in $\mathrm{FEV}_{1}>20 \%$ & 500 & 32 & 5 & 16 & No \\
\hline $\begin{array}{l}\text { McDonald et } \\
\text { al } 1972^{10}\end{array}$ & $\begin{array}{l}\text { Single blind, } \\
\text { controlled }\end{array}$ & $16-73$ & Allergy clinic & Rapid reduction in $\mathrm{FEV}_{1}$ & 1000 & 42 & 10 & 24 & No \\
\hline $\begin{array}{c}\text { Weber et al } \\
1979^{15}\end{array}$ & $\begin{array}{l}\text { Randomised, single } \\
\text { blind, placebo } \\
\text { controlled }\end{array}$ & $25-70$ & $\begin{array}{l}\text { Allergy and asthma } \\
\text { clinic }\end{array}$ & $\begin{array}{l}\text { Abnormal results for } \\
\text { pulmonary function tests, } \\
\text { including reduction in } \\
\mathrm{FEV}_{1}>25 \%\end{array}$ & 1000 & 15 & 0 & 0 & Yes \\
\hline $\begin{array}{l}\text { Szczeklik et } \\
\text { al } 1976^{30}\end{array}$ & $\begin{array}{l}\text { Single blind, placebo } \\
\text { controlled }\end{array}$ & Mean 27.2 & Not specified & Reduction in $\mathrm{FEV}_{1}>20 \%$ & 500 & 8 & 0 & 0 & Yes \\
\hline $\begin{array}{r}\text { Szczeklik et } \\
\text { al } 1977^{31} \\
\end{array}$ & $\begin{array}{l}\text { Single blind, placebo } \\
\text { controlled }\end{array}$ & $20-75$ & Allergy clinic & Reduction in $\mathrm{FEV}_{1}>20 \%$ & 1500 & 50 & $11^{*}$ & 22 & Yes \\
\hline $\begin{array}{c}\text { Delaney } \\
1976^{12}\end{array}$ & $\begin{array}{l}\text { Double blind, } \\
\text { placebo controlled }\end{array}$ & $14-72$ & Outpatients & $\begin{array}{l}\text { Reduction in } \mathrm{FEV}_{1}>20 \% \\
\text { from baseline for up to } \\
\text { four hours }\end{array}$ & 650 & 69 & 2 & 3 & Yes \\
\hline $\begin{array}{l}\text { Szczeklik et } \\
\text { al } 1977^{1}\end{array}$ & $\begin{array}{l}\text { Double blind, } \\
\text { placebo controlled }\end{array}$ & $16-68$ & $\begin{array}{l}\text { Allergy and clinical } \\
\text { immunology } \\
\text { department }\end{array}$ & $\begin{array}{c}\text { Reduction in peak } \\
\text { expiratory flow } 16-25 \% \\
\text { and clinical symptoms of } \\
\text { bronchial obstruction or } \\
\text { reduction in peak } \\
\text { expiratory flow }>25 \% \text { with } \\
\text { no symptoms }\end{array}$ & 600 & 49 & 3 & 6 & Yes \\
\hline $\begin{array}{l}\text { Vedanthan et } \\
\text { al } 1997^{22}\end{array}$ & $\begin{array}{c}\text { Double blind, } \\
\text { placebo controlled }\end{array}$ & $8-18$ & Outpatients & Reduction in $\mathrm{FEV}_{1}>20 \%$ & 600 & 3 & 1 & 33 & Yes \\
\hline $\begin{array}{l}\text { Total }(95 \% \\
\text { Cl)†‡ }\end{array}$ & & Not available & & & Not available & & & 6.5 (0 to 16.4$) \S$ & \\
\hline
\end{tabular}

$\mathrm{FEV}_{1}=$ forced expiratory flow in one second.

*Eight patients reacted to $1000 \mathrm{mg}$ or $1500 \mathrm{mg}$ and three reacted to $1500 \mathrm{mg}$ only.

†Cumulative dose over four hours.

¥Calculated from pooling incidence rate in individual studies.

$\S$ Lower bound truncated at 0.

with the results of provocation challenge-are warranted to confirm the prevalence of the data we have derived.

Our value for the prevalence of aspirin induced asthma in adult asthmatic patients is higher than the $10 \%$ reported in recent reviews. ${ }^{77}$ Methods and patient bias provide one explanation for this, since studies assessing patient history only resulted in lower estimates than those based on oral provocation testing. It is not surprising that asthmatic patients often do not report sensitivity to aspirin when questioned because many are unaware of this syndrome and do not associate the use of a pain reliever with an asthma attack. Indeed, $15 \%$ of asthmatic patients evaluated during a multicentre study spanning 10 European countries only became aware of their intolerance after provocation testing. ${ }^{38}$ Underdiagnosis of the syndrome may be due to the lack of routine testing by aspirin challenge in asthmatic patients who do not report a positive history of aspirin sensitivity. ${ }^{38}$

Analyses based on the use of a questionnaire resulted in a higher number of positive results than did retrospective analyses of medical records. Prevalence rates of $11-24 \%$ were given in the four studies using questionnaires, ${ }^{816} 1820$ whereas rates of 2-3\% were obtained from the three studies relying on medical records. ${ }^{26}{ }^{28}$ One explanation for this finding is that questionnaires are usually deployed within a set time frame and by a limited number of people, whereas medical records are likely to be completed by a larger number of different healthcare professionals - the absence of a recording of aspirin induced asthma does not necessarily mean that it was not present. Retrospective analysis of medical records is therefore an insensitive means of detecting aspirin induced asthma.

Cross sensitivity to NSAIDs occurred in most of the patients with aspirin induced asthma. In contrast, the pooled incidence of cross sensitivity to paracetamol among patients with the syndrome was only $7 \%$. Based on these data, less than $2 \%$ of asthmatic patients are likely to react to both paracetamol and aspirin. The available data indicate that patients who are highly sensitive to aspirin are more likely to be sensitive to paracetamol than those requiring higher doses of aspirin to elicit a response. The authors of one study pointed out that their patients were highly sensitive to aspirin-the mean provoking dose was only 47 $\mathrm{mg}$ of aspirin, compared with $1227 \mathrm{mg}$ of paracetamol. ${ }^{33}$ They also correlated aspirin dose and frequency of cross reactivity to paracetamol (fig 2), commenting that when the aspirin dose provoking a $20 \%$ reduction in forced expiratory volume in one second was $30 \mathrm{mg}, 83 \%(5 / 6)$ of patients reacted to paracetamol, but when the dose was $150 \mathrm{mg}$, none $(0 / 4)$ of the patients reacted to paracetamol. This study was also used to compare the severity of paracetamol induced bronchoconstriction with corresponding reactions to aspirin in the same patients. ${ }^{33}$ Although there was no significant difference in the magnitude of the

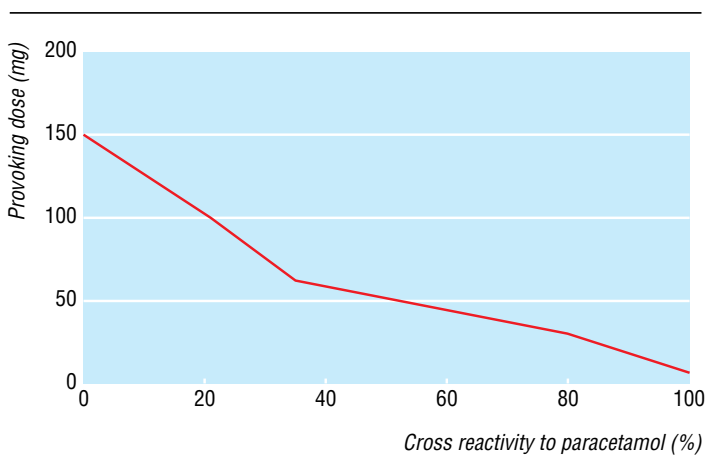

Fig 2 Relation between aspirin provoking dose and frequency of cross sensitivity to paracetamol (reproduced from Settipane et al $1995^{33}$ with permission of Mosby) 


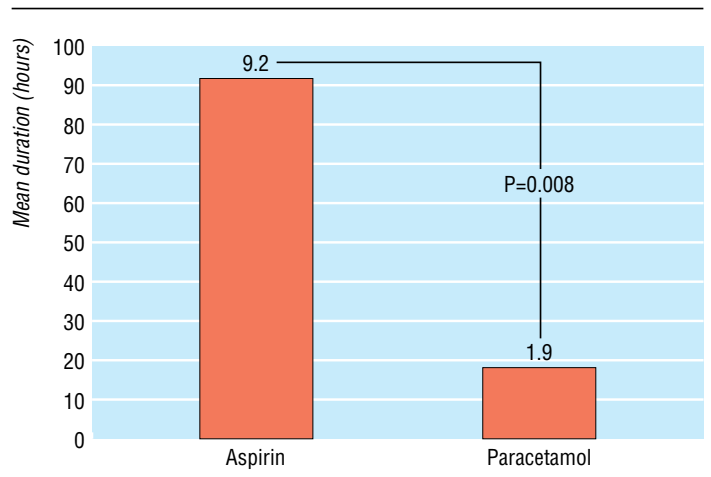

Fig 3 Duration of aspirin induced and paracetamol induced bronchospastic reactions (reproduced from Settipane et al $1995^{33}$ with permission of Mosby)

reduction in forced expiratory volume in one second with either product, the reaction to paracetamol was significantly shorter than that to aspirin (fig 3) and significantly milder, as shown by the mean number of nebuliser treatments required by the patients reacting to paracetamol $(1.2 v 2.6, \mathrm{P}=0.035)$.

The continuing recommendation of paracetamol as the analgesic and antipyretic of first choice for patients with asthma seems warranted given the relatively low incidence of sensitivity. The new generation of COX-2 specific analgesics may also be safer than NSAIDs and aspirin in asthmatic patients, but further experience with these compounds is required. Based on this conclusion, we have simplified guidelines for the use of analgesics in asthmatic patients (table 5). Where history neither supports nor excludes aspirin induced asthma, and aspirin or NSAIDs are clinically indicated, formal provocation testing is warranted, but because of the risk of severe bronchoconstriction this must be conducted by specialised staff with facilities for emergency resuscitation.

We found that a significant proportion of asthmatic patients are sensitive to aspirin. Many may be unaware of their sensitivity because either they have never taken aspirin or they developed aspirin induced asthma in adulthood after years of apparent tolerance. Since aspirin and NSAIDs are often self prescribed, patients diagnosed with asthma should be alerted to the possibility of aspirin induced asthma by their healthcare professional. Our data justifies the need to include simple, standardised warnings on packs of aspirin and NSAIDs, alerting asthmatic patients to the potential risks.

\section{Table 5 Guidelines for use of analgesics in asthmatic patients}

\begin{tabular}{|c|c|}
\hline Patient characteristics & Recommendation \\
\hline $\begin{array}{l}\text { Anyone positively identified with aspirin } \\
\text { induced asthma; or anyone who has ever } \\
\text { experienced an asthmatic reaction to } \\
\text { aspirin or NSAIDs (such as ibuprofen, } \\
\text { diclofenac, naproxen sodium); or anyone } \\
\text { with high risk features of aspirin induced } \\
\text { asthma (severe asthma symptoms, nasal } \\
\text { polyps, urticaria, or chronic rhinitis) }\end{array}$ & $\begin{array}{l}\text { Patient should avoid all products that contain } \\
\text { aspirin or NSAIDs indefinitely; paracetamol } \\
\text { should be recommended, unless } \\
\text { contraindicated }\end{array}$ \\
\hline $\begin{array}{l}\text { Younger than } 40 \text { years of age, or; have not } \\
\text { used aspirin or an NSAID recently without } \\
\text { incident }\end{array}$ & $\begin{array}{l}\text { Aspirin induced asthma may develop late in } \\
\text { life, so patients should be informed of risks } \\
\text { of aspirin and NSAIDs, and paracetamol } \\
\text { should be recommended, unless } \\
\text { contraindicated. If NSAIDs are necessary, the } \\
\text { first dose may be taken under medical } \\
\text { supervision }\end{array}$ \\
\hline All other asthmatic patients & $\begin{array}{l}\text { Any analgesic may be considered. If patients } \\
\text { experience any respiratory reactions in } \\
\text { response to therapy they should be advised } \\
\text { to stop treatment and visit a doctor }\end{array}$ \\
\hline
\end{tabular}

\section{What is already known on this topic}

Aspirin induced asthma is a distinct syndrome that is potentially life threatening

The prevalence and cross reactivity to other analgesics has been difficult to assess due to differences in trial methods

Asthmatic patients sensitive to aspirin are usually cross reactive to NSAIDs but seldom react to paracetamol

\section{What this study adds}

Aspirin induced asthma is more prevalent than previously suggested

Less than $2 \%$ of asthmatic patients are sensitive to both aspirin and paracetamol; reactions to paracetamol tend to be less severe

Contributors: All authors conceived and initiated this review. CJ performed the analysis and drafted the paper; she will act as guarantor for the paper. JC interpreted the results and helped with writing. LH helped with the research, interpretation, and writing.

Funding: CJ and LH are clinicians working partly in public hospital and private practice and in a research institute that receives funding from government, bequests, and many industry sources. Neither is directly funded by any manufacturer of non-steroidal anti-inflammatory drugs or paracetamol.

Competing interests: CJ has received payment from GlaxoSmithKline Consumer Healthcare Australia, the manufacturer of Panadol (paracetamol), for speaking at a conference. JC serves as a consultant on the Global Analgesics Advisory Board, which is funded by GlaxoSmithKline Consumer Healthcare.

Ethical approval: None required.

1 Szczeklik A, Gryglewski RJ, Czerniawska-Mysik G. Clinical patterns of hypersensitivity to nonsteroidal anti-inflammatory drugs and their pathogenesis. J Allergy Clin Immunol 1977;60:276-84.

2 Stevenson DD. Diagnosis, prevention, and treatment of adverse reactions to aspirin and nonsteroidal anti-inflammatory drugs. J Allergy Clin Immunol 1984;74:617-22.

3 Chandrasekharan NV, Dai H, Roos KL, Evanson NK, Tomsik J, Elton TS, et al. COX-3, a cyclooxygenase-1 variant inhibited by acetaminophen and other analgesic/ antipyretic drugs: cloning, structure, and expression. Proc Nat Acad Sci USA 2002;99:13926-31.

4 Schwab JM, Schluesener HJ, Laufer S. COX-3: just another COX or the solitary elusive target of paracetamol? Lancet 2003;361:981-2.

5 Stevenson DD, Simon RA. Lack of cross-reactivity between rofecoxib and aspirin in aspirin-sensitive patients with asthma. J Allergy Clin Immunol 2001;108:47-51.

6 Kwoh CK, Feinstein AR. Rates of sensitivity reactions to aspirin: problems in interpreting the data. Clin Pharmacol Ther 1986;40:494-505. 7 Levy S, Volans G. The use of analgesics in patients with asthma. Drug Safety

2001;24:829-41.
Vally H, Taylor ML, Thompson PJ. The prevalence of aspirin intolerant asthma (AIA) in Australian asthmatic patients. Thorax 2002;57:569-74.

9 Nizankowska E, Bestynska-Krypel A, Cmiel A, Szczeklik A. Oral and bronchial provocation tests with aspirin for diagnosis of aspirin-induced asthma. Eur Respir J 2000;15:863-9.

10 McDonald JR, Mathison DA, Stevenson DD. Aspirin intolerance in asthma. Detection by oral challenge. J Allergy Clin Immunol 1972;50:198-207.

11 Stevenson DD, Mathison DA, Tan EM, Vaughan JH. Provoking factors in bronchial asthma. Arch Intern Med 1975;135:777-83

12 Delaney JC. The diagnosis of aspirin idiosyncrasy by analgesic challenge. Clin Allergy Delaney JC. The

13 Stenius BSM, Lemola M. Hypersensitivity to acetylsalicylic acid (ASA) and tartrazine in patients with asthma. Clin Allergy 1976;6:119-29.

14 Spector SL, Wangaard CH, Farr RS. Aspirin and concomitant idiosyncrasies in adult asthmatic patients.J Allergy Clin Immunol 1979;64:500-6.

15 Weber RW, Hoffman M, Raine DAJ, Nelson HS. Incidence of bronchoconstriction due to aspirin, azo dyes, non-azo dyes, and preservatives in a population of perennial asthmatics. J Allergy Clin Immunol 1979;64:32-7.

16 Picado C, Castillo JA, Vennera MC, Gistau C, Burgos F, Agusti A. Aspirin intolerance: relationship with severity of clinical characteristics of asthma (abstract). Eur J Respir Dis 1982;63:226.

17 Falliers CJ. Acetaminophen and aspirin challenges in subgroups of asthmatics. J Asthma 1983:20:39-49.

18 Castillo J, Picado C. Prevalence of aspirin intolerance in asthmatics treated in a hospital. Respiration 1986;50:153-7.

19 Milosevic D. Intoleranz und allergie gegen analgetika. Allergologie Jahrgang 1990;13:205-9. 
20 Marquette CH, Saulnier F, Leroy O, Wallaert B, Chopin C, Demarcq JM, et al. Long-term prognosis of near-fatal asthma: a 6-year follow-up study of 145 asthmatic patients who underwent mechanical ventilation for a near-fatal attack of asthma. $A m$ Rev Respir Dis 1992;146:76-81.

21 Rachelefsky GS, Coulson A, Siegel SC, Stiehm ER. Aspirin intolerance in chronic childhood asthma: detected by oral challenge. Pediatrics 1975;56:443-8.

22 Vedanthan PK, Menon MM, Bell TD, Bergin D. Aspirin and tartrazine oral challenge: incidence of adverse response in chronic childhood asthma. I Allergy Clin Immunel 1997;60:8-13.

23 Schuhl JF, Pereyra JG. Oral acetylsalicylic acid (aspirin) challenge in asthmatic children Clin Allergy 1979;9:83-8.

24 Fischer TJ, Guilfoile TD, Kesarwala HH, Winant JGJ, Kearns GL, Gartside PS, et al Adverse pulmonary responses to aspirin and acetaminophen in chronic childhood asthma. Pediatrics 1983;71:313-8

25 Towns SJ, Mellis CM. Role of acetyl salicylic acid and sodium metabisulfite in chronic childhood asthma. Pediatrics 1984;73:631-7.

26 Walton CHA, Randle DL. Aspirin allergy. Can Med Assoc J 1957;76:1016-8.

27 Pearson RSB. Hypersensitivity to aspirin. In: Dixon A, Martin KB, eds. Salicylates: an international symposium. London: Churchill, 1963:170-3.

28 Chafee FH, Settipane GA. Aspirin intolerance I. Frequency in an allergic population.J Allergy Clin Immunol 1974;53:193-9

29 Falliers CJ. Aspirin and subtypes of asthma: risk factor analysis.J Allergy Clin Immuno 1973;52:141-7.

30 Szczeklik A, Gryglewski RJ, Czerniawska-Mysik G, Zmuda A. Aspirin-induced asthma. Hypersensitivity to fenoprofen and ibuprofen in relation to their inhibitory action on prostaglandin generation by different microsomal enzymatic preparations. I Allergy Clin Immunol 1976;58:10-8.

31 Szczeklik A, Gryglewski RJ, Czerniawska-Mysik G, Pieton R. Asthmatic attacks induced in aspirin-sensitive patients by diclofenac and naproxen. BMJ 1977;2:231-2.

32 Quiralte J. Intolerance to nonsteroidal antiinflammatory drugs: results of controlled drug challenges in 98 patients. J Allergy Clin Immunol 1996;98:678-85.
33 Settipane RA, Schrank PJ, Simon RA, Mathison DA, Christiansen SC, Stevenson DD Prevalence of cross-sensitivity with acetaminophen in aspirin-sensitive asthmatic subjects. J Allergy Clin Immunol 1995;96:480-5.

34 Szczeklik A, Gryglewski RJ, Czerniawska-Mysik G. Relationship of inhibition of prostaglandin biosynthesis by analgesics to asthma attacks in aspirin-sensitive patients. BMJ 1975;1:67-9.

35 Barles PG, Duce GF, Portillo OJ, Perez AJ, Escuer AJ. Adverse reaction of acetaminophen as an alternative analgesic in AAS triad. Allergol Immunopathol (Madr) 1988;16:321-5.

36 Ispano M, Fontana A, Scibilia J, Ortolani C. Oral challenge with alternative nonsteroidal antiinflammatory drugs (NSAIDs) and paracetamol in patients intolerant to these agents. Drugs 1993;46:253-6.

37 Szczeklik A, Sanak M. Molecular mechanisms in aspirin-induced asthma. Allergy Clin Immunol Int 2000;12:171-6.

38 Szczeklik A, Nizankowska E, Duplaga M. Natural history of aspirin-induced asthma. Eur Respir J 2000;16:432-6.

(Accepted 14 November 2003)

bmj.com 2004;328:434

Woolcock Institute of Medical Research, Royal Prince Alfred Hospital, Camperdown, NSW 2050, Australia

Christine Jenkins head, asthma group

King's College Hospital, London SE5 9RS

John Costello clinical director of medicine

Asthma Centre, Royal Prince Alfred Hospital

Linda Hodge dietitian

Correspondence to: C Jenkins, Suite 702, 26 Ridge Street, North Sydney, NSW 2060, Australia crj@med.usyd.edu.au 